\title{
PENGARUH PENGGUNAAN MODEL PEMBELAJARAN KOOPERATIF TIPE PICTURE AND PICTURE TERHADAP HASIL BELAJAR PENDIDIKAN AGAMA ISLAM
}

\author{
P-ISSN: 2089-4341 | E-ISSN: 2655-9633 \\ Link: https://uia.e-journal.id/akademika/article/view/814 \\ DOI: 10.34005 /akademika.v9i01.814 \\ Abdul Rofik Khalim \\ rofik.mg25@gmail.com \\ Marliza Oktapiani \\ marlizaoktapiani.fai@uia.ac.id \\ Universitas Islam As-Syafi'iyah Indonesia \\ Universitas Islam As-Syafi'iyah Indonesia
}

\begin{abstract}
Abstrak: Penelitian ini bertujuan (1) untuk mengetahui bagaimana gambaran penggunaan model pembelajaran kooperatif tipe picture and picture pada mata pelajaran Pendidikan Agama Islam, (2) menganalisa adakah pengaruh yang signifikan (kuat) pada penggunaan model pembelajaran kooperatif tipe picture and picture terhadap hasil belajar siswa pada mata pelajaran Pendidikan Agama Islam. Metode yang digunakan dalam penelitian ini adalah metode eksperimen. Adapun teknik pengambilan sampel dilakukan dengan simple random sampling dan dikategorikan ke dalam dua kelompok yaitu kelas eksperimen dan kelas kontrol. Teknik pengambilan data primer dilakukan dengan tes soal hasil belajar Pendidikan Agama Islam yang terdiri dari 34 soal yang valid dan memiliki reliabilitas kuat yaitu sebesar 0,811. Data sekunder dengan melakukan dokumentasi. Tes soal diujikan setelah adanya perlakuan (treatment) model pembelajaran yang berbeda pada kelas eksperimen dan kontrol. Penelitian ini dianalisis dengan uji T (Independent Sample Test) menggunakan program Microsoft Excel 2010. Kesimpulannya adalah model pembelajaran kooperatif tipe picture and picture memberikan pengaruh yang signifikan terhadap hasil belajar siswa pada mata pelajaran Pendidikan Agama Islam di kelas VIII SMPN 4 Tambun Selatan, Bekasi.
\end{abstract}

Kata Kunci: Model Pembelajaran Kooperatif, Picture And Picture, Hasil Belajar Pendidikan Agama Islam

\begin{abstract}
This study aims (1) to find out how the picture of the use of cooperative learning models of picture and picture types in Islamic Religious Education subjects, (2) analyze whether there is a significant (strong) effect on the use of cooperative learning models of Picture and Picture types on student learning outcomes in Islamic Religious Education subjects. The method used in this research is the experimental method. The sampling technique is done by simple random sampling and categorized into two groups, namely the experimental class and the control class. The primary data collection technique was carried out with a test of Islamic Religious Education learning outcomes which consisted of 34 valid questions and had a strong reliability of 0.811 . Secondary data by documenting. The test questions were tested after the treatment of different learning models in the experimental and control classes. This study was analyzed by $T$ test (Independent Sample Test) using Microsoft Excel 2010. The results is
\end{abstract}


the cooperative learning model of picture and picture type has a significant influence on student learning outcomes in Islamic Religious Education subjects in class VIII of SMPN 4 Tambun Selatan, Bekasi.

Keywords: Cooperative Learning, Picture and Picture, Learning Outcomes Education Islamic Religion

\section{PENDAHULUAN}

Dalam mewujudkan suatu tujuan dari pendidikan, maka diperlukan suatu proses belajar. Terkait hal tersebut Nana Syaodih Sukmadinata (20164:155) mengatakan bahwa belajar merupakan suatu proses perubahan dalam tingkah laku yang mengarah kepada tingkah laku yang lebih baik. Tingkah laku mengalami perubahan karena belajar menyangkut berbagai aspek kepribadian, baik fisik maupun psikis, seperti pemecahan suatu masalah atau berfikir, keterampilan, kecakapan, kebiasaan, sikap ataupun pengalaman. Setiap orang memiliki cara untuk merubah dirinya dengan cara merencanakan kearah yang lebih baik sehingga perubahan tersebut didapatkan dari proses pembelajaran.

Perencanaan pembelajaran merupakan salah satu faktor utama dalam proses keberhasilan kegiatan belajar mengajar di sekolah, baik di dalam kelas maupun di luar kelas. Oleh karena itu, hasil pembelajaran yang diinginkan tidak dapat tercapai tanpa adanya perencanan, dengan perencanaan yang baik akan menghasilkan kegiatan pembelajaran yang optimal. Selain perencanaan pembelajaran yang menjadi salah satu faktor dalam ketercapaian suatu pembelajaran, juga terdapat kendala yang dihadapi pada pendidikan Indonesia saat ini. Abdul Majid (2014:1) Pendidikan nasional masih rendah mutunya, kurang relevansinya dengan kebutuhan pembangunan, kurang efektif dan efisien pelaksanaanya. Salah satu dampak kegagalan pendidikan nasional adalah krisis akhlak dan moral. Krisis ini, secara langsung atau tidak, berhubungan dengan kegagalan pendidikan agama, termasuk di dalamnya pendidikan agama Islam. Untuk mengantisipasi berbagai krisis tersebut, maka pembelajaran agama Islam di sekolah harus menunjukkan kontribusinya. Ahmad Fathullah (https://ahmad fathullah.blogspot.com/2017/07/penga-ruhglobalisasi-terhadap.html, 4-09-2018) negara berkembang pada saat yang sama menciptakan sistem-sistem, Kehidupan manusia saat ini sangat dipengaruhi oleh globalisasi ditinjau dari berbagai aspek kehidupan, baik aspek sosial politik, ekonomi, kebudayaan begitupula pendidikan menerima perkembangan zaman dan kemajuan teknologi yang sebagian besar bersumber dari negara-negara barat seperti: televisi, handphone, komputer, interner dan lain-lain, tidak terkecuali pendidikan Islam yang tidak bisa lepas dari bias fenomena globalisasi ini. Sebagai fenomena globaliasi tak lepas tuntutannya dengan mengharapkan perubahan dan perbaikan melalui Pendidikan Islam yang mampu memainkan perannya 
secara dinamis dan proaktif. Apabila dikaitkan dengan peranan guru sebagai salah satu faktor dalam keberhasilan belajar siswa, maka diperlukan upaya yang serius yang dilakukan oleh seorang guru untuk mencari faktor awal yang dapat mempengaruhi keberhasilan belajar siswa tersebut.

Dalam pandangan Fauziah Nur'aini Kurdi (2009:109) di Indonesia saat ini masih ditemukan sistem pembelajaran bersifat satu arah, sehingga guru hanya menyelesaikan target pada rencana pembelajaran, menuntaskan isi didalam buku pelajaran tanpa pmengedepankan pembelajaran dua arah, guru lebih terlihat dominan sehingga terlihat masih menggunakan pembelajaran secara konvensional (ceramah dan memberi tugas) dan masih dianggap belum maksimal. Dampak dari sistem pembelajaran tersebut guru kurang mengembangkan bahan pembelajaran dan cenderung seadanya (monoton). Terkait hal tersebut Ruslina (Skripsi, 2017:3) menyatakan bahwa guru sebagai salah satu sumber belajar siswa hanya menggunakan pembelajaran yang bersifat teacher centered (berpusat pada guru), di mana guru mendominasi kegiatan pembelajaran sehingga siswa hanya mendengar dan mencatat penjelasan guru. Hal tersebut mengakibatkan siswa kurang aktif sehingga kurang menumbuhkan kemampuan berfikir siswa. Sebagai pendidik, guru hanya menerapkan dan menyampaikan materi kepada siswa dengan metode konvensional atau metode ceramah yang terkadang dibantu media power point akan tetapi cara mengajar seperti itu masih belum efektif karena komunikasi guru bersifat satu arah tanpa melibatkan peran aktif dari siswa. Disini siswa cenderung hanya sebagai penerima transfer pengetahuan dari guru tanpa diberi kesempatan untuk menggali potensi yang dimiliki oleh siswa. Penyampaian materi yang dilakukan guru kurang menarik perhatian siswa juga mengakibatkan siswa menjadi cepat bosan dan jenuh, kurangnya kreativitas siswa dan minat belajar serta pengetahuan yang rendah. Perlu menjunjung tinggi kompetensi guru yang mengedepankan kompetensi pedagogik, guru pula mampu menciptakan suasana pembelajaran yang kreatif, aktif dan menyenangkan, berbagi ilmu serta memecahkan permasalahan bersama berdasarkan temuan persitiwa yang perlu digali, siswa dituntun untuk mecari solusi dari setiap masalah yang ditemukan serta guru pula mampu memanfaatkan model pembelajaran sesuai dengan kebutuhan tema yang ada, Oleh karena itu, tujuan pendidikan akan tercapai secara optimal apabila para pendidik maupun para siswa didukung oleh penggunaan model yang tepat.

Berdasarkan latar belakang di atas, maka penulis tertarik untuk melakukan penelitian dengan Judul pengaruh penggunaan model pembelajaran kooperatif tipe picture and picture terhadap hasil belajar siswa pada mata pelajaran Pendidikan Agama Islam di kelas VIII SMPN 4 Tambun Selatan, Bekasi.

Adapun rumusan masalah dalam penelitian ini adalah: 1) Bagaimana gambaran penggunaan model pembelajaran kooperatif tipe 
picture and picture pada mata pelajaran Pendidikan Agama Islam di kelas VIII SMPN 4 Tambun Selatan, Bekasi? 2) Apakah terdapat pengaruh penggunaan model pembelajaran kooperatif tipe picture and picture terhadap hasil belajar siswa pada mata pelajaran Pendidikan Agama Islam di kelas VIII SMPN 4 Tambun Selatan, Bekasi?

Adapun tujuan penelitian ini adalah 1) Untuk mengetahui gambaran penggunaan model pembelajaran kooperatif tipe picture and picture pada mata pelajaran Pendidikan Agama Islam di kelas VIII SMPN 4 Tambun Selatan, Bekasi. 2) Untuk mengetahui pengaruh penggunaan model pembelajaran kooperatif tipe picture and picture terhadap hasil belajar siswa pada mata pelajaran Pendidikan Agama Islam di kelas VIII SMPN 4 Tambun Selatan, Bekasi.

Benny A. Pribadi (2009:10-11) menyatakan untuk menciptakan aktivitas pembelajaran maka diperlukan rencana yang terstruktur agar semua terpenuhi dengan baik. Pembelajaran bersifat eksternal dan sengaja dirancang untuk mendukung terjadinya proses belajar internal dalam diri individu. Adapun tujuan dari lembaga pendidikan Islam itu sendiri diharapkan mampu untuk membawa peserta didik mencapai tujuan yang meliputi: tumbuh dan meningkatnya keimanan peserta didik melalui pemberian dan pemupukan pengetahuan, penghayatan, pengamalan serta pengalaman peserta didik tentang agama Islam sehingga menjadi manusia muslim yang terus berkembang dalam hal keimanan, ketakwaannya kepada Allah SWT.

Model dirancang untuk mewakili realitas sesungguhnya, walaupun model itu sendiri bukanlah realitas dari dunia sebenarnya. Model pembelajaran adalah pola yang digunakan sebagai pedoman dalam merencanakan pembelajaran di kelompok maupun tutorial (Agus Suprijono, 2011: 46). Sejalan dengan pendapat di atas, menurut Joyce yang di kutip oleh Trianto (2011:22), model pembelajaran adalah suatu perencanaan atau suatu pola yang digunakan sebagai pedoman dalam merencanakan pembelajaran dikelas atau pelajaran dalam teritoria I dan untuk menentukan perangkat-perangkat pembelajaran termaksud didalamnya buku-buku, film, komputer, kurikulum, dan lain-lain. Setiap model pembelajaran mengarahkan kita dalam mendesain pembelajaran untuk membantu peserta didik sedemikian rupa sehingga tujuan pembelajaran tercapai. Jadi model pembelajaran menjadi suatu hal yang harus dipahami secara baik dan mendalam bagi para guru yang menyajikan berbagai pelajaran khususnya pelajaran Pendidikan Agama Islam. Selanjutnya Winata Putra dikutip oleh Junaedah dan Sigit Wibowo (2016 : 7) berpendapat bahwa model pembelajaran adalah kerangka konseptual yang melukiskan prosedur yang sistematis dalam mengorganisasikan pengalaman belajar untuk mencapai tujuan belajar tertentu dan berfungsi sebagai pedoman bagi para perancang pembelajaran dan para pengajar dalam merencanakan dan melaksanakan aktivitas pembelajaran. Berdasarkan pengertian para ahli diatas, maka dapat disimpulkan bahwa model pembelajaran adalah suatu pola atau 
perencanaan yang di rancang untuk menciptakan pembelajaran di kelas secara efektif dan efisien untuk mencapai tujuan pembelajaran. Model pembelajaran dapat dijadikan sebagai salah satu cara untuk meningkatkan kualitas pembelajaran di kelas. Selanjutnya Davidson dan Kroll dikutip oleh Edi Kurniawan dan Mulyadi (2016 : 6) menjelaskan bahwa pembelajaran kooperatif setidaknya terdapat lima prinsip yang dianut yaitu: 1) Belajar Siswa Aktif, yaitu proses pembelajaran berpusat pada siswa dan aktivitas belajar lebih dominan dilakukan siswa; 2) Belajar Kerjasama yaitu siswa secara langsung terlibat secara aktif dalam kelompok untuk melakukan diskusi; 3) Pembelajaran Partisipatorik, yaitusiswa melakukan kerjasama untuk menemukan dan membangun pengetahuan yang menjadi tujuan bersama; 4) Reactive Teaching, yaitu guru perlu menciptakan suasana belajar yang menarik dan menyenangkan sehingga siswa mempunyai motivasi belajar yang tinggi; dan 5) Pembelajaran yang Menyenengkan, yaitu model pembelajaran tidak akan berjalan secara efektif jika suasana belajar yang ada tidak menyenangkan. Model-model pembelajaran memiliki banyak variasi, salah satunya model pembelajaran tipe picture and picture. Model pembelajaran kooperatif tipe picture and picture adalah suatu model pembelajaran dengan menggunakan gambar-gambar sebagai media dalam proses pembelajaran dimana gambar-gambar tersebut dipasangan ataupun diurutkan menjadi urutan yang logis, model pembelajaran kooperatif tipe picture and picture bertujuan untuk menarik perhatian siswa sehingga siswa dapat fokus dan dalam keadaan yang menyenangkan saat mengikuti pelajaran. Jadi, Pembelajaran perlu bercirikan yaitu kreatif, aktif, inovatif dan menyenangkan. Sehingga apa yang telah di sampaikan oleh pendidik melalui model pembelajaran dapat meresap dan difahami secara rinci oleh peserta didik. Adapun salah satu model pembelajaran yang digunakan di Indonesia yaitu model pembelajaran kooperatif tipe picture and picture, model ini bercirikan dengan mengandalkan gambar sebagai media dalam proses pembelajaran. Gambar-gambar ini menjadi faktor utama dalam proses pembelajaran. Sehingga sebelum proses pembelajaran, guru sudah menyiapkan gambar yang akan ditampilkan baik dalam bentuk kartu atau dalam bentuk cerita.

Menurut Imas Kurniasih (2015: 44), model pembelajaran kooperatif tipe picture and picture merupakan model pembelajaran kooperatif atau mengutamakan adanya kelompok-kelompok dengan menggunakan media gambar yang dipasangkan atau diurutkan menjadi urutan logis dan model ini siswa diajak secara sadar dan terencana untuk mengembangkan interaksi diantara mereka agar bisa saling asah, saling asih dan saling asuh dan model ini memiliki karakteristik yang inovatif, kreatif, dan tentu saja sangat menyenangkan. Sedangkan model pembelajaran kooperatif tipe picture and picture menurut Hamdani (2010:89) adalah salah satu model pembelajaran aktif yang menggunakan gambar dan dipasangkan atau diurutkan yang 
sistematis. Seperti menyusun gambar secara berurutan, menunjukkan gambar, memberi keterangan dan menjelaskan gambar.

Model pembelajaran picture and picture adalah salah satu pembelajaran kooperatif. Model pembelajaraan kooperatif merupakan model pembelajaran yang banyak digunakan dan menjadi perhatian serta dianjurkan oleh para ahli pendidik. Berdasarkan hasil penelitian yang dilakukan oleh Slavin dinyatakan bahwa: (1) penggunaan pembelajaran kooperatif dapat meningkatkan prestasi belajar siswa dan sekaligus dapat meningkatkan hubungan sosial, menumbuhkan sikap toleransi, dan menghargai pendapat orang lain, (2) pembelajaran kooperatif dapat memenuhi kebutuhan siswa dalam berfikir kritis, memecahkan masalah, dan mengintergrasikan pengetahuan dengan pengalaman. Dengan alasan tersebut, strategi pembelajaran kooperatif diharapkan mampu meningkatkan kualitas pembelajaran (Rusman, 2013:205). Dari pengertian diatas dapat disimpulkan bahwa model pembelajaran kooperatif tipe picture and picture adalah salah satu model pembelajaran aktif yang menggunakan gambar dan dipasangkan atau diurutkan menjadi urutan yang sistematis, seperti menyusun gambar secara berurutan, menunjukkan gambar, memberikan keterangan gambar dan menjelaskan gambar.

Model pembelajaran diharapkan dapat meningkatkan hasil belajar, hasil belajar dapat diperoleh dari siswa setelah melalui kegiatan belajar. Setelah mengetahui hasil belajar siswa, maka dapat diketahui apakah tujuan pembelajaran telah tercapai atau belum. Menurut Sudjana (2011:22) hasil belajar yaitu suatu perubahan yang terjadi pada individu yang belajar, bukan hanya perubahan mengenai pengetahuan, tetapi juga untuk membentuk kecakapan, kebiasaan, pengertian, penguasaan dan penghargaan dalam diri sesorang yang belajar. Sedangkan menurut Dimyati dan Mudjiono (2009:20) mengemukakan bahwa hasil belajar adalah hasil yang ditunjukkan dari suatu interaksi tindak belajar dan biasanya ditunjukkan dengan nilai tes yang diberikan guru. Sedangkan menurut Hamalik (2009:159) bahwa hasil belajar menunjukkan kepada prestasi belajar, sedangkan prestasi belajar merupakan indikator adanya derajat perubahan tingkah laku siswa.

Susanto (2014:5) mengemukakan bahwa makna hasil belajar yaitu perubahan-perubahan yang terjadi dalam diri siswa, baik menyangkut aspek kognitif, afektif, dan psikomotor sebagai hasil kegiatan belajar. Nawawi dalam Susanto (2014:5) menyatakan hasil belajar dapat diartikan sebagai tingkat keberhasilan siswa dalam mempelajari materi pelajaran di sekolah dinyatakan dalam skor yang diperoleh dari hasil tes mengenai sejumlah materi pelajaran tertentu.

Hasil belajar selanjutnya menurut Hamalik yang dikutip oleh Murtaqiatusholihat dan Khasanah (2015:50) adalah segala sesuatu yang menjadi milik siswa sebagai akibat dari kegiatan belajar yang dilakukannya. Hasil belajar yaitu perubahan-perubahan yang terjadi pada 
diri siswa, baik yang menyangkut aspek kognitif, afektif, dan psikomotorik sebagai hasil dari kegiatan belajar.Berdasarkan pendapat di atas dapat disimpulkan bahwa hasil belajar merupakan perubahan pada dirinya. Baik perubahan tingkah lakunya maupun pengetahuannya. Perubahan itu dapat dilihat dari hasil yang diperoleh siswa setelah melakukan tes yang diberikan oleh guru setelah memberikan materi pembelajaran pada suatu materi, apabila hasil belajar tercapai dengan baik, maka sikap dan tingkah lakunya akan berubah menjadi baik pula. Rujukan penelitian terdahulu dalam penelitian ini diantaranya: 1) Jurnal Pendidikan Guru Sekolah Dasar (PGSD) (2014: 79-87) yang diterbitkan dalam Jurnal Pesona Dasar, Volume 02 No.03 di Universitas Universitas Syiah Kuala, dengan judul Penerapan Model Kooperatif Tipe Picture and Picture pada Materi Peninggalan Sejaran di Sekolah Dasar Negeri Banda Aceh. 2) Jurnal Pendidikan Sejarah (2017:243-252) yang diterbitkan dalam Jurnal FACTUM , Volume 6 No.2 di Universitas Pendidikan Indonesia, dengan judul Penerapan Model Cooperative Learning Tipe Picture and Picture untuk Meningkatkan Kemampuan Berpikir Kronologis Siswa dalam Pembelajaran Sejarah. 3) Jurnal Program Studi Pendidikan Biologi (2018:10-21) yang diterbitkan dalam Jurnal Bio Educatio, Volume 3 No.1 di Universitas Majalengka, dengan judul Penerapan Model Pembelajaran Kooperatif Tipe Picture and Picture untuk Meningkatkan Hasil Belajar Siswa SMP pada Pembelajaran IPA. 4) Jurnal (2018) Jurnal Pendidikan yang diterbitkan dalam Jurnal Pendidikan dan Pembelajaran Katulistiwa, Volume 7 No. 4 di Universitas Tanjungpura Pontianak, dengan judul Peningkatan Keterampilan Menulis Paragraf Menggunakan Cooperative Learning Tipe Picture and Picture di Sekolah Dasar. 5) Jurnal Pendidikan Sekolah Dasar (2018:1-14) yang diterbitkan dalam Jurnal JPSD, Volume 4 No.1 di Universitas Pakuan Bogor, dengan judul Pengaruh Penerapan Model Pembelajaran Picture and Picture dan Model Make A Match terhadap Hasil Belajar Siswa. 6) Jurnal Pendidikan Guru Sekolah Dasar (2014) yang diterbitkan dalam e-Journal MIMBAR PGSD Volume 2 No.1 di Universitas Pendidikan Ganesha, dengan judul Pengaruh Model Pembelajaran Picture and Picture terhadap Keterampilan Menulis Wacana Narasi Siswa Kelas IV Semester I tahun Pelajaran 2013/2014 di Gugus VII Kecamatan Sukasada. 7) Journal of ICSAR (2017) yang diterbitkan pada journal of ICSAR, Volume 1 No.2 di Universitas Negeri Malang dengan judul The Effect of Picture and Picture Learning Model towards Science Outcomes for Students with Hearing Impairment in the Class VII. 8) Jurnal Pendidikan Bahasa (2019:294-308) yang diterbitkan dalam Jurnal Pendidikan Bahasa, Volume 8 No.2 di IKIP PGRI Pontianak dengan judul Keefektifan Model Pembelajaran Kooperatif Tipe Picture and Picture dan Think-Pair-Share dalam Pembelajaran Menulis Deskripsi. 9) Jurnal Sekolah Dasar (2018:30-38), yang diterbitkan di Elementary School Journal, Volume 1 No.3 di Universitas Buana Perjuangan Karawang dengan judul Penerapan Model Kooperatif Tipe Picture and Picture dalam 
Pembelajaran Kemampuan Berbicara Siswa Sekolah Dasar. 10) Skripsi Henny Kiswanti (2013) yang diterbitkan di Universitas Negeri Semarang, dengan judul Peningkatan Kualitas Pembelajaran IPA Melalui Model Kooperatif Tipe Picture and Picture pada Siswa Kelas II SD Negeri Bawen 05.

\section{Hipotesis Penelitian}

Berdasarkan landasan teori dan kerangka berfikir yang telah diuraikan diatas, maka sesuai dengan permasalahan dan tujuan penelitian dapatlah diajukan hipotesis sebagai berikut:1) Diduga terdapat gambaran penggunaan model pembelajaran kooperatif tipe Picture And Picture pada mata pelajaran Pendidikan Agama Islam di kelas VIII SMPN 4 Tambun Selatan, Bekasi 2) Diduga terdapat pengaruh yang signifikan pada penggunaan model pembelajaran kooperatif tipe Picture and Picture terhadap hasil belajar siswa pada mata pelajaran Pendidikan Agama Islam di kelas VIII SMPN 4 Tambun Selatan, Bekasi.

\section{METODE}

Metode yang digunakan dalam penelitian ini adalah metode kuantitatif dalam Sugiyono (2008). Tempat penelitian adalah lokasi di mana penelitian dilakukan. Penelitian ini dilaksanakan di kelas VIII SMP Negeri 4 Tambun Selatan - Bekasi yang beralamat di Jl. Raya Jatimulya No.185, Kelurahan Jatimulya, Kecamatan Tambun Selatan Kabupaten Bekasi. Adapun penelitian ini dilaksanakan pada bulan Oktober 2018 sampai dengan bulan Januari 2019

Dalam penelitian ini, peneliti menentukan yang menjadi variabel bebas (inependent variable) adalah model pembelajaran kooperatif tipe picture and picture, dan yang menjadi variabel terikat (dependent variable) adalah hasil belajar siswa pada bidang studi Pendidikan Agama Islam. Maka peneliti membagi subjek/objek yang diteliti menjadi dua grup yaitu grup treatment atau yang memperoleh perlakuan (model pembelajaran kooperatif tipe picture and picture) di kelas VIII.8 sebagai kelas eksperimen dan grup kontrol yang tidak memperoleh perlakuan yaitu kelas VIII.3. Populasi terjangkaunya adalah seluruh siswa di kelas VIII SMPN 4 Tambun Selatan - Bekasi sejumlah 473 siswa.

Teknik pengambilan sampel yang digunakan dalam penelitian eksperimen ini dengan menggunakan Simple Random Sampling. Kelompok dalam penelitian ini adalah siswa kelas VIII.1, VIII.2, VIII.3, VIII.4, VIII.5, VIII.6, VIII.7, VIII.8, VIII.9, VIII.10, VIII.11, VIII.12, VIII.13. Semua siswa kelas VIII adalah homogen, maka pengambilan sampelnya dipilih menggunakan teknik pengambilan sampel acak sederhana atau simple random sampling untuk menentukan kelas ekperimen dan kelas kontrol. Oleh karena itu, seluruh siswa kelas VIII memiliki kesempatan untuk menjadi sampel. Setelah dilakukan pengundian maka sampel dalam 
penelitian ini adalah siswa kelas VIII.8 dengan jumah 34 siswa sebagai kelas eksperimen dan kelas VIII.3 dengan jumlah 34 sebagai kelas kontrol.

Pada penelitian ini digunakan tes soal untuk mengungkap data hasil belajar. Tes hasil belajar yang digunakan peneliti adalah tes tertulis dalam bentuk pilihan ganda dengan empat alternatif jawaban yaitu a, b, c, dan d. Dari empat alternatif jawaban itu hanya ada satu jawaban yang benar. Skor dari tes ini digunakan sebagai ukuran kemampuan siswa. Tes hasil belajar dilakukan satu kali. Adapun tes hasil belajar Pendidikan Agama Islam terdiri dari 40 soal pilihan ganda. Tes ini digunakan untuk mengukur pencapaian hasil belajar siswa. Metode ini digunakan untuk mendapatkan data tentang tingkat hasil belajar Pendidikan Agama Islam (PAI). Tahap selanjutnya melakukan Uji Validitas Instrumen. Dalam hal ini peneliti menyediakan butir soal minimal 15 yang dapat dilakukan koefisien korelasi antar skor totalnya dan menggunakan formula product moment dari person. Kriteria acuan untuk indeks korelasi (r) butir soal dilakukan atas dasar membandingkan nilai hitung $r_{x y}$ dari masing-masing butir soal dengan rabel untuk taraf signifikan $5 \%(0,05)$ dengan responden sebanyak 34 orang. Nilai $r_{\text {tabel }}$ untuk 34 orang responden adalah $\mathrm{df}=\mathrm{N}-2$ adalah 0,404 . Maka butir soal valid apabila nilai hitung $r_{x y}>0,404$ sedangkan butir soal tidak valid (drop) apabila nilai hitung $r_{x y}<0,404$. Tahap selanjutnya yaitu Uji Reliabilitas Instrumen Berdasarkan pengujian melalui program Microsoft Excel 2010 maka diperoleh reliabilitas soal hasil belajar Pendidikan Agama Islam adalah sebesar 0,809.

\section{HASIL}

Pada penelitian ini akan menyajikan atau mendeskripsikan hasil penelitian untuk variabel meodel pembelajaran kooperatif tipe picture and picture dan variabel hasil belajar Pendidikan Agam Islam. Data yang dideskripsikan ini diperoleh dari skor soal berupa butir soal yang telah disusun oleh penulis berdasarkan indikator-indikatornya yang disebarkan kepada siswa-siswi kelas kontrol dan eksperimen. Hasil penelitian tentang pengaruh kelas yang mendapatkan perlakuan meodel pembelajaran kooperatif tipe picture and picture dan yang tidak mendapatkan perlakuan terhadap hasil belajar Pendidikan Agama Islam di kelas VIII SMP Negeri 4 Tambun Selatan - Bekasi adalah sebagai berikut:

\section{Distribusi Frekuensi Skor Soal Kelals Eksperimen}

Dari data yang diperoleh di lapangan yang kemudian diolah secara statistik ke dalam daftar distribusi frekuensi, banyaknya kelas dihitung menurut aturan sturges, diperoleh enam kelas dengan nilai skor minimum 75 dan skor maksimum 100, sehingga rentang skor sebesar 25. Berdasarkan hasil perhitungan statistik deskriptif diperoleh bahwa skor hasil belajar siswa yang menggunakan model pembelajaran kooperatif tipe picture and picture mempunyai nilai rata-rata (mean) sebesar 90,15 
dengan nilai standar deviasi 6,68 dimana nilai median 90 . Pengelompokkan data dapat terlihat pada table 1 distribusi frekuensi sebagai berikut:

Tabel 1. Distribusi Skor Hasil Belajar Siswa Kelas Eksperimen

\begin{tabular}{|c|c|c|c|}
\hline \multicolumn{4}{|c|}{ Kelas Interval Eksperimen } \\
\hline No & Skor Hasil Belajar & Frekuensi & $F(\%)$ \\
\hline 1 & $75-79$ & 1 & $3 \%$ \\
\hline 2 & $80-84$ & 4 & $12 \%$ \\
\hline 3 & $85-89$ & 6 & $18 \%$ \\
\hline 4 & $90-94$ & 10 & $29 \%$ \\
\hline 5 & $95-99$ & 8 & $24 \%$ \\
\hline 6 & $100-104$ & 5 & $15 \%$ \\
\hline \multicolumn{2}{|c|}{ Jumlah } & 34 & $100 \%$ \\
\hline
\end{tabular}

Berdasarkan pengolahan data di atas dapat diperoleh nilai rata-rata hitung (mean) sebesar 90,15 nilai ini setara dengan 90,15: $104 \times 100 \%=$ $86,6 \%$, dari kemungkinan skor tertinggi. Dengan demikian skor hasil belajar kelas eksperimen termasuk dalam kategori cukup baik.

\section{Distribusi Frekuensi Skor Soal Kelas Kontrol}

Dari data yang diperoleh di lapangan yang kemudian diolah secara statistik ke dalam daftar distribusi frekuensi, banyaknya kelas dihitung menurut aturan sturges, diperoleh enam kelas dengan nilai skor minimum 55 dan skor maksimum 80, sehingga rentang skor sebesar 25. Berdasarkan hasil perhitungan statistik deskriptif diperoleh bahwa skor hasil belajar siswa pada kelas kontrol yang tidak memperoleh perlakuan yaitu mempunya nilai rata-rata (mean) sebesar 66,47 dengan nilai standar deviasi 5,84 dimana nilai median 65 . Pengelompokkan data dapat terlihat pada tabel distribusi frekuensi sebagai berikut:

Tabel 2. Distribusi Skor Hasil Belajar Siswa Kelas Kontrol

\begin{tabular}{llll}
\hline \multicolumn{3}{l}{ Kelas } & Interval Kontrol \\
\hline No. & Skor Hasil Belajar & Frekuensi & $\mathbf{F}(\%)$ \\
\hline $\mathbf{1}$ & $55-59$ & 2 & $6 \%$ \\
$\mathbf{2}$ & $60-64$ & 6 & $18 \%$ \\
$\mathbf{3}$ & $65-69$ & 12 & $35 \%$ \\
$\mathbf{4}$ & $70-74$ & 9 & $26 \%$ \\
$\mathbf{5}$ & $75-79$ & 4 & $12 \%$ \\
$\mathbf{6}$ & $80-84$ & 1 & $3 \%$ \\
\multicolumn{2}{l}{ Jumlah } & 34 & $100 \%$ \\
\hline
\end{tabular}

Berdasarkan pengolahan data di atas dapat diperoleh nilai rata-rata hitung (mean) sebesar 66,47 nilai ini setara dengan 66,47:84 $\times 100 \%=$ $79,1 \%$ dari kemungkinan skor tertinggi. Dengan demikian skor hasil belajar kelas kontrol termasuk dalam kategori cukup baik.

\section{Pengujian Persyaratan Analisis}


Uji prasyarat analisis merupakan hal yang penting dilakukan sebelum pengujian hipotesis. Pengujian prasyarat ini akan memudahkan peneliti dalam menentukan jenis teknik analisis atau statistik uji apa yang akan digunakan. Beberapa teknik analisis seperti uji-t mensyaratkan perlunya asumsi distribusi normal dan homogen. Pengujian normalitas dan homogenitas dilakukan terhadap dua buah data, yaitu hasil belajar kelas eksperimen dan kelas kontrol. Persyaratan yang harus dipenuhi dalam uji t student adalah bahwa sampel penelitian berasal dari populasi yang berdistribusi normal dan varians data sampel homogen. Berkaitan dengan hal tersebut, sebelum dilakukan pengujian model, terlebih dahulu dilakukan pengujian terhadap kedua persyaratan yang berlaku dalam uji $t$ student tersebut.

\section{Uji Normalitas Data}

Data yang digunakan dalam uji t student harus memenuhi asumsi bahwa data tersebut berasal dari populasi yang berdistribusi normal. Uji asumsi tersebut dalam penelitian ini dilaksanakan dengan menguji normalitas data skor hasil belajar dari kedua sampel yaitu kelas eksperimen (menggunakan model pembelajaran kooperatif tipe picture and picture) dan kelas kontrol (menggunakan metode konvensional) yang akan dianalisis. Pengujian persyaratan normalitas dilakukan dengan menggunakan bantuan program Microsoft Excel 2010. Kriteria pengujian terima $H_{\circ}$ jika nilai $p>0,05$ yang menyatakan bahwa skor berdistribusi normal, dalam hal lainnya $\mathrm{H}_{\mathrm{o}}$ tidak dapat diterima. Kriteria pengujiannya adalah sebagai berikut:

$H_{0}$ : Data sampel berdistribusi normal, jika nilai $p>0,05$

$\mathrm{H}_{1}$ : Data sampel tidak berdistribusi normal, jika nilai $\mathrm{p}<0,05$

Dari hasil analisis pada tabel di atas diperoleh $L$ hitung $\left(L_{0}\right)=0,0447$, sedangkan pada tabel liliefors pada $a=0,05$ dengan $(n=34)$ diperoleh $L$ tabel $\left(L_{t}\right)=0,1519$. Ini berarti $L$ hitung $\left(L_{0}\right)$ lebih kecil dari $L$ tabel $\left(L_{t}\right)$. Dengan demikian dapat disimpulkan bahwa data sampel kelas eksperimen berasal dari populasi yang berdistribusi normal. Dan $\mathrm{H}_{0}$ diterima karena data sampel berasal dari populasi berdistribusi normal.

\section{Uji Homogenitas Varians}

Uji homogenitas varians dimaksudkan untuk menguji homogenitas varians antara kelompok-kelompok eksperimen dan control. Pengujian homogenitas varians dilakukan dengan uji levene. Dari hasil perhitungan diperoleh $F_{\text {hitung }}=1,309$. pada taraf $5 \%$ dan diperoleh $F_{\text {tabel }}=1,788$. Dengan demikian dapat disimpulkan bahwa $F_{\text {hitung }}<F_{\text {tabel, }}$ maka dapat diinterpretasikan bahwa variansi kedua kelas adalah homogen.

Tabel 3. Uji Homogenitas Varians Menggunakan SPSS V.22 


\begin{tabular}{lccc}
\hline \multicolumn{4}{c}{ Test of Homogeneity of Variances } \\
$\begin{array}{l}\text { Hasil Belajar } \\
\text { Levene }\end{array}$ & $\mathrm{df1}$ & $\mathrm{df2}$ & $\mathrm{Sig}$. \\
$\begin{array}{l}\text { Statistic } \\
, 309\end{array}$ & 1 & 66 &, 580 \\
\hline
\end{tabular}

Berdasarkan hasil pengolahan pengujian homogenitas varians kelas eksperimen dan kelas kontrol di atas, dapat diperoleh nilai $p$ sebesar 0,580 maka $\mathrm{H}_{0}$ diterima. Hal ini berarti varians kelas eksperimen dan kelas kontrol adalah homogen.

Tabel 4. Hasil Uji t Melalui Microsoft Excel

t-Test: Two-Sample Assuming Equal Variances

\begin{tabular}{lll}
\hline & Variable 1 & Variable 2 \\
\hline Mean & 66,47058824 & 90,14705882 \\
Variance & 34,13547237 & 44,67468806 \\
Observations & 34 & 34 \\
Pooled Variance & 39,40508021 & \\
Hypothesized Mean Difference & 0 & \\
Df & 66 & \\
t Stat & 20,428838 \\
$\mathrm{P}(\mathrm{T}<=\mathrm{t})$ one-tail & $4,68084 \mathrm{E}-24$ \\
t Critical one-tail & 1,668270515 \\
$\mathrm{P}(\mathrm{T}<=\mathrm{t})$ two-tail & $9,36167 \mathrm{E}-24$ & \\
t Critical two-tail & 1,996564396 & \\
\hline
\end{tabular}

Diketahui :

$S_{1}^{2}=34,13$

$S_{2}^{2}=44,67$

$\mathrm{t}=\frac{x_{1}-x_{2}}{\sqrt{\frac{s_{g}^{2}}{m_{1}}+\frac{s_{g}^{2}}{m_{2}}}}=\frac{90,14-66,47}{\sqrt{\frac{30,40}{34}+\frac{32,40}{34}}}=15,675$

Nilai thitung $(15,675)$ lebih besar daripada nilai tabel $(1,668)$, sehingga hipotesis nol ditolak. Dengan demikian dapat disimpulkan bahwa skor hasil belajar kelas eksperimen (menggunakan model pembelajaran kooperatif tipe picture and picture) lebih tinggi daripada kelas kontrol. 


\section{PEMBAHASAN}

\section{Hipotesis 1}

Penggunaan model pembelajaran kooperatif tipe Picture and Picture terhadap hasil belajar siswa pada mata pelajaran Pendidikan Agama Islam di kelas VIII SMPN 4 Tambun Selatan, Bekasi dapat dilaksanakan dengan baik dan mendapatkan respon yang positif dari siswa. Guru membuka kegiatan belajar dengan memberikan pengantar. Guru terlibat aktif dalam proses belajar, yaitu guru menjelaskan pembelajaran dan memperlihatkan gambar-gambar yang telah disiapkan, langkah selanjutnya guru membagi siswa ke dalam beberapa kelompok dan menentukan ketua kelompoknya, ketua kelompok diberikan gambar yang telah di siapkan dalam keadaan teracak, kemudian masing-masing kelompok mengerjakan tugas dengan cara mengurutkan atau menyusun gambar-gambar (pictures) yang masih teracak dan mendiskusikannya serta dituangkan kedalam tulisan. Kemudian guru memberikan kesempatan dan mengarahkan siswa agar dapat berfikir sistematis, setelah itu masing-masing ketua kelompok untuk maju kedepan kelas, yaitu guru menanyakan alasan yang logis terkait gambar yang mereka kerjakan. Melalui kegiatan ini siswa dilatih untuk berfikir secara sistematis, melatih siswa percaya diri dalam mempresentasikan jawabannya di depan kelas, sedangkan siswa atau kelompak yang lain dapat menulis atau merangkum apa yang di presentasikan oleh kelompok yang maju kedepan, maka aspek kognitif terpenuhi. Aspek afektifnya, siswa dilatih untuk mematuhi aturan model pembelajaran yang disepakati dengan tetap menjaga kondisi kelas. Sedangkan aspek psikomotorik, siswa atau anggota kelompok dapat kesempatan untuk menjawab dan mengurutkan/menyusun gambar yang telah diberikan oleh guru. Dibawah ini proses pembelajaran dengan menggunakan tipe picture and picture. Gambaran penggunaan model pembelajaran ini sejalan dengan pendapat Davidson dan Kroll yang dikutip oleh Edi Kurniawan dan Mulyadi (2016:6) menjelaskan bahwa pembelajaran kooperatif setidaknya terdapat lima prinsip yang dianut yaitu: 1) Belajar Siswa Aktif, yaitu proses pembelajaran berpusat pada siswa dan aktivitas belajar lebih dominan dilakukan siswa; 2) Belajar Kerjasama yaitu siswa secara langsung terlibat secara aktif dalam kelompok untuk melakukan diskusi; 3) Pembelajaran Partisipatorik, yaitu siswa melakukan kerjasama untuk menemukan dan membangun pengetahuan yang menjadi tujuan bersama; 4) Reactive Teaching, yaitu guru perlu menciptakan suasana belajar yang menarik dan menyenangkan sehingga siswa mempunyai motivasi belajar yang tinggi; 
dan 5) Pembelajaran yang Menyenangkan, yaitu model pembelajaran tidak akan berjalan secara efektif jika suasana belajar yang ada tidak menyenangkan. Adapun hasil penelitian ini didukung dokumentasi proses pembelajaran dengan menggunakan model pembelajaran kooperatif tipe picture and picture.

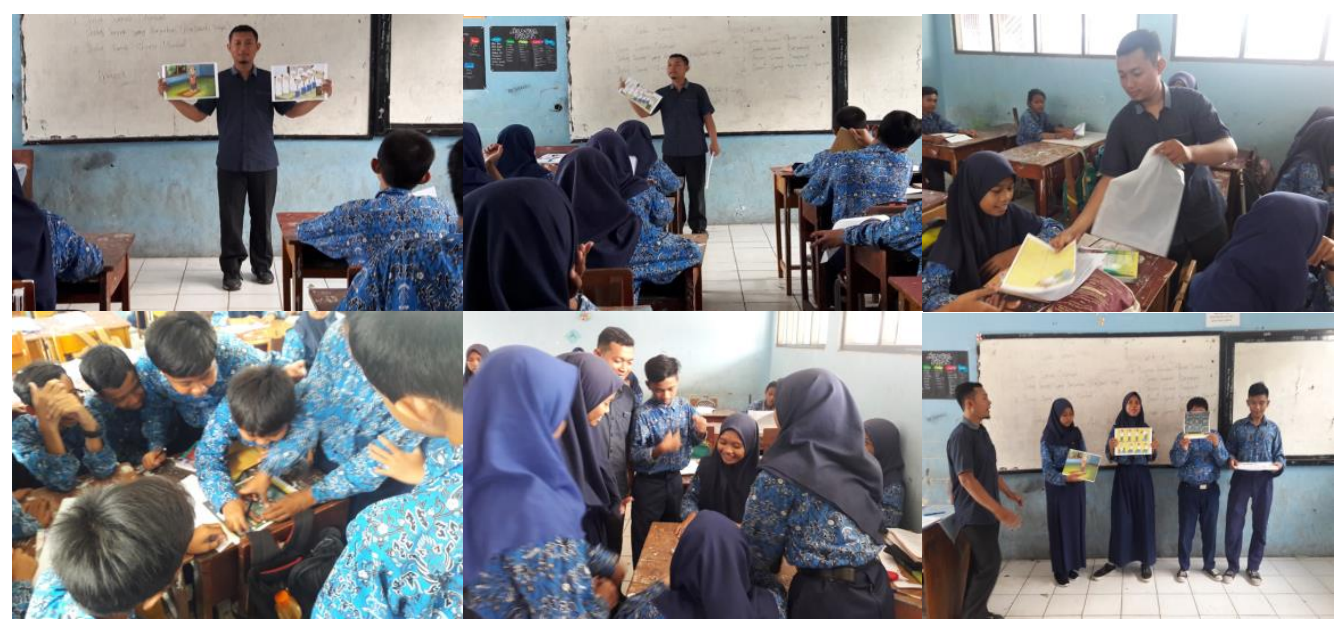

Gambar 1. Proses pembelajaran dengan menggunakan tipe picture and picture

\section{Hipotesis 2}

Pelaksanaan penelitian ini bertujuan untuk mengetahui sejauh mana pengaruh model pembelajaran kooperatif tipe picture and picture terhadap hasil belajar siswa pada mata pelajaran Pendidikan Agama Islam di kelas VIII di SMPN 4 Tambun Selatan, Bekasi

Berdasarkan hasil data yang telah diolah dan dianalisa, hasil belajar siswa yang menggunakan model pembelajaran kooperatif tipe picture and picture lebih besar daripada siswa yang tidak menggunakan model pembelajaran kooperatif tipe picture and picture. Dari hasil perhitungan dengan menggunakan uji t menggunakan $t_{\text {tabel }}$ yang diperoleh sebesar 1,668 dan thitung sebesar 15,675. Ternyata nilai thitung lebih besar dari $t_{\text {tabel }}$, dimana $t_{\text {itung }}=15,675>\mathrm{t}_{\text {tabel }}=1,668$. Dengan demikian $\mathrm{H}_{0}$ ditolak dan $\mathrm{H}$ d diterima, maka penggunaan model pembelajaran kooperatif tipe picture and picture terhadap hasil belajar siswa pada mata pelajaran Pendidikan Agama Islam di kelas VIII SMPN 4 Tambun Selatan, Bekasi memiliki pengaruh yang signifikan. Penelitian sejalan dengan pendapat Isjoni pada model Kooperatif siswa diberi kesempatan untuk berkomunikasi dan berinteraksi sosial dengan temannya untuk mencapai tujuan pembelajaran, sementara guru bertindak sebagai motivator dan fasilitator aktivitas siswa. Artinya dalam pembelajaran ini kegiatan aktif dengan pengetahuan dibangun sendiri oleh siswa dan mereka bertanggung jawab atas hasil pembelajarannya.

Sama halnya dengan penelitian terdahulu yang menghasilkan analisis terdapat pengaruh penggunaan model pembelajaran kooperatif 
tipe picture and picture terhadap hasil belajar siswa yang artinya apabila guru menerapkan model pembelajaran yang bervariasi dan memiliki kompetensi dalam menghidupkan suasana pembelajaran serta memberikan kesempatan untuk menggunakan model pembelajaran yang kreatif, aktif dan menyenangkan maka target dari hasil pembelajaran akan tercapai dapat dilihat dari ketuntasan minimum pembelajaran dan hasil belajar setiap siswa, dengan adanya model pembelajaran membuat guru lebih terdorong untuk mengemas materi menjadi lebih sederhana dan mudah difahami oleh siswa. Siswa yang memiliki hasil belajar yang baik akan disertai perubahan pada dirinya baik melalui kebiasaan, kecakapan, penguasaan maupun penghargaan untuk dirinya dalam mempertahankan hasil belajar.

\section{Keterbatasan Penelitian}

Penelitian dengan judul Pengaruh Penggunaan Model Kooperatif tipe picture and picture terhadap hasil belajar siswa pada pengujian pengaruh antara kedua variabelnya. Untuk keperluan ini, peneliti menggunakan bantuan SPSS Versi 22. Keterbatasan dalam penelitian ini adalah berhubungan dengan sulitnya peneliti mendapatkan hasil yang dijawab oleh responden berdasarkan keseriusan dalam membaca pertanyaan di angket, selain itu waktu dan dana penelitian yang sangat terbatas, karena untuk mendapatkan penelitian yang akurat perlu adanya data yang berulang didapatkan dari hasil pengukuran.

\section{KESIMPULAN}

Adapun beberapa kesimpulan yang dapat ditarik adalah sebagai berikut: 1) Model pembelajaran kooperatif tipe Picture and Picture terhadap hasil belajar siswa pada mata pelajaran Pendidikan Agama Islam di kelas VIII SMPN 4 Tambun Selatan, Bekasi dapat dilaksanakan dengan baik dan mendapatkan respon yang positif dari siswa. Guru membuka kegiatan belajar dengan memberikan pengantar. Guru terlibat aktif dalam proses belajar, yaitu guru menjelaskan pembelajaran dan memperlihatkan gambar-gambar yang telah disiapkan, langkah selanjutnya guru membagi siswa ke dalam beberapa kelompok dan menentukan ketua kelompoknya, ketua kelompok diberikan gambar yang telah di siapkan dalam keadaan teracak, kemudian masing-masing kelompok mengerjakan tugas dengan cara mengurutkan atau menyusun gambar-gambar (pictures) yang masih teracak dan mendiskusikannya serta dituangkan kedalam tulisan. 2) Pengaruh penggunaan model pembelajaran kooperatif tipe picture and picture terhadap hasil belajar siswa bisa dikatakan cukup kuat (signifikan). Hal ini dapat dilihat dari beberapa hasil pengujian yang telah dilakukan peneliti berupa tes soal kepada kelas eksperimen yaitu pada uji t menggunakan ttabel yang 
diperoleh sebesar 1,668 dan thitung sebesar 15,675 . Ternyata nilai thitung lebih besar dari ttabel, dimana thitung $=15,675>$ ttabel $=1,668$ pada taraf signifikansi $5 \%$ dan $n=34$. Dengan demikian bahwa $\mathrm{HO}$ ditolak dan $\mathrm{H} 1$ dierima, sehingga terdapat pengaruh yang signifikan pada penggunaan model pembelajaran kooperatif tipe picture and picture terhadap hasil belajar siswa pada mata pelajaran Pendidikan Agama Islam di Kelas VIII SMPN 4 Tambun Selatan, Bekasi.

\section{DAFTAR PUSTAKA}

Ainin, Yaumil \& Dwi, Wiwik. (2017). The Effect of Picture and Picture Learning Model towards Science Outcomes for Students with Hearing Impairment in the Class VII Journal of ICSAR, 1 (2):145149.

Arif, Aden Gaffar. (2018). Penerapan Model Pembelajaran Kooperatif Tipe Picture and Picture untuk Meningkatkan Hasil Belajar Siswa SMP pada Pembelajaran IPA Jurnal Bio Educatio, 3 (1): 10-21.

Beni, Ahmad Pribadi. (2009). IImu Pendidikan Islam. Bandung: CV Pustaka Setia.

Fathullah, Ahmad (http//ahmad fathullah.blogspot.com/2017/07/pengaruhglobalisasi-terhadap.html.

Fauziah, Tati \& Bermawi, Yoserizal. (2014). Penerapan Model Kooperatif Tipe Picture and Picture pada Materi Peninggalan Sejaran di Sekolah Dasar Negeri Banda Aceh. Jurnal Pendidikan Guru Sekolah Dasar (PGSD), Jurnal Pesona Dasar, 2(03): 79-87

Fenny, Feby,I,W \& Doi, Maksimilianus (2019)) Keefektifan Model Pembelajaran Kooperatif Tipe Picture and Picture dan Think-PairShare dalam Pembelajaran Menulis Deskripsi Jurnal Pendidikan Bahasa, 8 (2):294-308.

Giri, Anggi,P \& Nurul, Dina. (2018) Penerapan Model Kooperatif Tipe Picture and Picture dalam Pembelajaran Kemampuan Berbicara Siswa Sekolah Dasar. Elementary School Journal, 1 (3): 30-38.

Hadi, Noer Pratomo \& Wiyanarti, Erlina. (2017). Penerapan Model Cooperative Learning Tipe Picture and Picture untuk Meningkatkan Kemampuan Berpikir Kronologis Siswa dalam Pembelajaran Sejarah Jurnal Pendidikan Sejarah, 6 (2): 243-252.

Hamalik, Oemar. (2009). Kurikulum dan Pembelajaran. Jakarta. Bumi Aksara.

Hamdani, (2010). Strategi Belajar Mengajar. Bandung: Pustaka Setia.

Isjoni. (2009). Cooperative Learning Mengembangkan Kemampuan Belajar Berkelompok. Bandung: Alfabeta

Junaedah, Wibowo, S. (2016). Pengaruh Model Pembelajaran Sentra dan Disiplin Belajar terhadap Kemampuan Matematika Siswa, Akademika Jurnal Teknologi Pendidikan , 5(01): 59-76. 
Kiswanti, Henny. (2013). Peningkatan Kualitas Pembelajaran IPA Melalui Model Kooperatif Tipe Picture and Picture pada Siswa Kelas II SD Negeri Bawen 05, (https://lib.unnes.ac.id/18155/1/1401911003.pdf).

Kurdi, Fauziah Nur'ani. (2009). Penerapan Student Centered Learning dari Teacher Centered Learning. Mata Ajar IImu Kesehatan pada Program Studi Penjasker, Jurnal Forum Kependidikan Volume 28, No. 2. Lihat Forum Kependidikan unsri.ac.id.

Kurniasih, Imas, Sani ,B. (2015). Ragam Pengembangan Model Pembelajaran untuk Peningkatan Profesionalitas Guru. Yogyakarta: Kata Pena.

Kurniawan, Edi, Mulyadi (2016) Pengaruh Model Pembelajaran Jigsaw dan Disiplin Belajar Siswa terhadap Hasil Belajar Ilmu Pengetahuan Sosial (IPS) Siswa, Akademika Jurnal Teknologi Pendidikan, 5(01): $1-18$.

Majid, A. (2014). Belajar dan Pembelajaran Pendidikan Agama Islam, Bandung: PT Remaja Rosdakarya, Cet. Ke-2.

Murtaqiatusholihat, Khasanah. (2016). Pengaruh Metode Pembelajaran Role Playing dan Kecerdasan Emosional Siswa terhadao Hasil Belajar Siroh, Akademika Jurnal Teknologi Pendidikan, 5(2): 43-70.

Mudjiono. (2009). Belajar dan Pembelajaran. Jakarta: PT. Rineka Cipta.

Nana Syaodih Sukmadinata. (2004). Landasan Psikologi Proses Pendidikan. Bandung: Remaja Rosdakarya.

Pribadi, Benny A. (2009). Model Desain Sistem Pembelajaran. Jakarta: Dian Rakyat.

Ruslina. (2017). Pengaruh Penerapan Model Kooperatif Picture and picture Terhadap Hasil Belajar Mata Pelajaran IPS Siswa Kelas V SD Islam Al Hasanah Ciledug-Tangerang. Jakarta : Skripsi di UIN Syarif Hidayatullah.

Rusman. (2013). Model-Model Pembelajaran Mengembangkan Profesionalisme Guru Edisi Kedua. Jakarta: PT. Raja Grafindo Persada, Cet. Ke-VI.

Sudjana. (2011). Penilaian Hasil Proses Belajar Mengajar. Bandung: PT Remaja Rosydakarya.

Sugiyono. (2008). Metode Penelitian Pendidikan, Bandung: Alfabeta.

Suprijono,Agus. (2011). Cooperative Learning. Yogyakarta: Pustaka Pelajar.

Susanto, Ahmad. (2014). Pengembangan Pembelajaran IPS di Sekolah Dasar Edisi Pertama. Jakarta: Prenadamedia Group.

Suwastini, Luh \& Arini, Ni Wayan. (2014). Pengaruh Model Pembelajaran Picture and Picture terhadap Keterampilan Menulis Wacana Narasi Siswa Kelas IV Semester I tahun Pelajaran 2013/2014 di Gugus VII Kecamatan Sukasada e-Journal MIMBAR PGSD, 2 (1).

Trianto. (2013). Model Pembelajaran Terpadu. Jakarta: Bumi Aksara.

Utaminingsih, Tri. (2018). Peningkatan Keterampilan Menulis Paragraf Menggunakan Cooperative Learning Tipe Picture and Picture di 
Sekolah Dasar, Jurnal Pendidikan dan Pembelajaran Katulistiwa, 7( 4).

Prihatiningsih, Eko \& Widyanti Eunice Setyanigtyas. (2018). Pengaruh Penerapan Model Pembelajaran Picture and Picture dan Model Make A Match terhadap Hasil Belajar Siswa, Jurnal JPSD, 4 (1):1-1 
